\title{
The faah gene is the first direct target of estrogen in the testis: role of histone demethylase LSD1
}

\author{
Paola Grimaldi - Mariangela Pucci - Sara Di Siena - Daniele Di Giacomo • \\ Valentina Pirazzi · Raffaele Geremia - Mauro Maccarrone
}

Received: 12 December 2011/Revised: 19 June 2012/ Accepted: 21 June 2012

(C) Springer Basel AG 2012

\begin{abstract}
Estrogen $\left(\mathrm{E}_{2}\right)$ regulates spermatogenesis, yet its direct target genes have not been identified in the testis. Here, we cloned the proximal $5^{\prime}$ flanking region of the mouse fatty acid amide hydrolase (fah) gene upstream of the luciferase reporter gene, and demonstrated its promoter activity and $E_{2}$ inducibility in primary mouse Sertoli cells. Specific mutations in the $\mathrm{E}_{2}$ response elements (ERE) of the faah gene showed that two proximal ERE sequences (ERE2/3) are essential for $\mathrm{E}_{2}$-induced transcription, and chromatin immunoprecipitation experiments showed that $\mathrm{E}_{2}$ induced estrogen receptor $\beta$ binding at ERE2/3 sites in the faah promoter in vivo. Moreover, the histone demethylase LSD1 was found to be associated with ERE2/3 sites and to play a role in mediating $\mathrm{E}_{2}$ induction of FAAH
\end{abstract}

P. Grimaldi, M. Pucci and S. Di Siena contributed equally to this work.

Electronic supplementary material The online version of this article (doi:10.1007/s00018-012-1074-6) contains supplementary material, which is available to authorized users.

P. Grimaldi $(\bowtie) \cdot$ S. Di Siena · D. Di Giacomo · R. Geremia Department of Public Health and Cellular Biology,

University of Rome "Tor Vergata", 00133 Rome, Italy

e-mail: paola.grimaldi@uniroma2.it

Present Address:

M. Pucci · V. Pirazzi · M. Maccarrone ( $\square)$

Department of Biomedical Sciences, University of Teramo,

Piazza A. Moro, 45, 64100 Teramo, Italy

e-mail: mmaccarrone@unite.it

M. Maccarrone

European Center for Brain Research (CERC)/Santa Lucia

Foundation, 00164 Rome, Italy expression. $\mathrm{E}_{2}$ induced epigenetic modifications at the faah proximal promoter compatible with transcriptional activation by remarkably decreasing methylation of both DNA at $\mathrm{CpG}$ site and histone $\mathrm{H} 3$ at lysine 9. Finally, FAAH silencing abolished $\mathrm{E}_{2}$ protection against apoptosis induced by the FAAH substrate anandamide. Taken together, our results identify FAAH as the first direct target of $\mathrm{E}_{2}$.

Keywords Endocannabinoids · Estrogen · FAAH · LSD1 $\cdot$ Testis $\cdot$ Spermatogenesis

$\begin{array}{ll}\text { Abbreviations } \\ \text { AEA } & \text { Anandamide } \\ \text { AR } & \text { Androgen receptor } \\ \text { BSA } & \text { Bovine serum albumin } \\ \text { CB }_{1} & \text { Type-1 cannabinoid receptor } \\ \text { CB }_{2} & \text { Type-2 cannabinoid receptor } \\ \text { ChIP } & \text { Chromatin immunoprecipitation } \\ \mathrm{E}_{2} & 17 \beta \text {-estradiol } \\ \text { epiE } & \\ \text { ER } \beta & \text { 17 } \alpha \text {-estradiol } \\ \text { ERE } & \text { Estrogen receptor } \beta \\ \text { FAAH } & \text { Estrogen-response element } \\ \text { FSH } & \text { Fatty acid amide hydrolase } \\ \text { HMT } & \text { Follicle-stimulating hormone } \\ \text { HDT } & \text { Histone methylase } \\ \text { LSD1 } & \text { Histone demethylase } \\ \text { MSP-PCR } & \text { Histone lysine demethylase 1 } \\ \text { Parg } & \text { Pargylinion-specific PCR } \\ \text { PBS } & \text { Phosphate-buffered saline } \\ \text { PFA } & \text { Paraformaldheyde } \\ \text { SDS-PAGE } & \text { Sodium dodecyl sulfate-polyacrylamide gel } \\ & \text { electrophoresis } \\ \text { TMX } & \text { Tamoxifen }\end{array}$




\section{Introduction}

Spermatogenesis is controlled by gonadotrophins and testosterone and is modulated by a complex network of endocrine and paracrine factors, among which are estrogens [1]. The biological effects of $17 \beta$-estradiol $\left(\mathrm{E}_{2}\right)$ are mediated by the estrogen receptors $\alpha(\operatorname{ER} \alpha)$ and $\beta(\operatorname{ER} \beta)$, which belong to the nuclear receptor superfamily and function as ligand-induced transcriptional factors. ERs regulate gene expression in a ligand-responsive manner through a classical nuclear mechanism, by direct interaction with estrogen-response elements (EREs) in the promoter of target genes [2]. DNA-bound ERs undergo conformational changes, which lead to cofactor recruitment and gene transcription by altering chromatin structure. In the testis of adult mice, both ER types have been identified: $\mathrm{ER} \alpha$ is localized in Leydig cells, whereas ER $\beta$ is expressed in Sertoli cells and most germ cells [3]. Although ER $\alpha$ has also been detected in rat Sertoli cells [4], no clear evidence documented its presence in the same cells of mice. Growing interest in the effects of $E_{2}$ in male reproduction is linked to the observation that ERs knockout [5] or disruption of $E_{2}$ synthesis [6] impair male fertility. Although some putative direct target genes of $E_{2}$ have been found in the testis [7-9], up to now the identification of a testicular cell-specific ER responsive promoter has not been reported.

In this investigation, we identified fatty acid amide hydrolase (FAAH) as a direct target gene of $E_{2}$ in mouse Sertoli cells. FAAH hydrolyzes the two most prominent endocannabinoids, $\mathrm{N}$-arachidonoylethanolamine (anandamide, AEA) and 2-arachidonoylglycerol. These substances play manifold roles in both the central nervous system and in the periphery $[10,11]$, reproductive organs included [12], mainly by activating G-protein coupled type- $1\left(\mathrm{CB}_{1}\right)$ and type- $2\left(\mathrm{CB}_{2}\right)$ cannabinoid receptors [13]. In the seminiferous tubules of the testis, both germ cells and somatic Sertoli cells possess a complete biochemical machinery to synthesize, transport, degrade and bind AEA and 2-arachidonoylglycerol [14-16]. Both endocannabinoids affect male reproductive functions: 2-arachidonoylglycerol has a pivotal role in spermatogenesis, by promoting the meiotic progression of germ cells [16]; AEA controls sperm functionality by reducing motility, capacitation, and acrosome reaction [17, 18], and it also reduces the spermatogenic output by inducing apoptosis of Sertoli cells [15]. AEA signaling depends on its endogenous content, that in vivo is strongly controlled by FAAH [19]. Remarkably, recent studies have shown that among the different components of the "endocannabinoid system" (i.e., AEA-binding receptors and metabolic enzymes) in Sertoli cells, only FAAH is a target of follicle-stimulating hormone (FSH) [14, 15]. FSH regulates FAAH expression and activity by triggering both protein kinase A- and aromatase-dependent transduction pathways [15]. Aromatase activation leads to the conversion of androgens to estrogens with the production of $E_{2}$, which stimulates FAAH expression at the transcriptional and translational level by unknown molecular mechanisms [15].

In this study, we have characterized the regulation of faah gene expression by $\mathrm{E}_{2}$. We demonstrate that $\mathrm{E}_{2}$ engages $\mathrm{ER} \beta$, which binds to ERE sites in the faah proximal promoter, and that the histone demethylase LSD1 is recruited at this site. We also show that $E_{2}$ induces demethylation of both DNA at $\mathrm{CpG}$ site and histone $\mathrm{H} 3$ at lysine 9 (H3K9) in the faah proximal promoter, so that $\mathrm{E}_{2}$-stimulated FAAH expression protects Sertoli cells against apoptosis induced by AEA.

\section{Materials and methods}

\section{Chemicals}

Chemicals were of the purest analytical grade. $17 \beta$-estradiol $\left(\mathrm{E}_{2}\right), 17 \alpha$-estradiol (epiE $\mathrm{E}_{2}$ ), tamoxifen (TMX), Fulvestrant (ICI 182780), pargyline (Parg) hydrochloride and anandamide ( $N$-arachidonoylethanolamine, AEA) were purchased from Sigma-Aldrich (St. Louis, MO, USA). S-Adenosyl$L$-[methyl- $\left.{ }^{3} \mathrm{H}\right]$ methionine $(63 \mathrm{Ci} / \mathrm{mmol})$ was from Amersham Biosciences (Buckinghamshire, UK).

Rabbit anti-LSD1 and anti-WT1 antibodies were from Abcam (Cambridge, UK), rabbit anti-ER $\beta$ and anti- $\beta$-actin antibodies were from Santa Cruz Biotechnology (Santa Cruz, CA, USA), and rabbit anti-H3K9me3 antibody was from Millipore (Billerica, MA, USA).

\section{Plasmids}

The murine faah promoter nucleotide spanning from -723 to +10 was amplified by polymerase chain reaction (PCR) using the following primers: forward 5'-GTCCTG AAGTTACCTCACTAG-3 ${ }^{\prime}$ and reverse $5^{\prime}$-TGCAGGAGA TCATGGTGCTGA- ${ }^{\prime}$. PCR products were cloned into XhoI/HindIII sites of pGL3 basic vector (Promega Corp., Madison, WI, USA). The $-560 /+10$ deletion mutant was obtained by PCR, using specific primers (forward AGACG TAGGTAGATAGCCCAGAGT, and reverse TGCAGG AGATCATGGTGCTGA); the $-250 /+10$ deletion mutant was obtained after digestion with $\mathrm{SacI}$. All the other sitespecific mutants were obtained by PCR amplification, using primers mutated in the ERE sequences, as follows: ERE1: 5'-TAGGGTGTGCATTACACTAA-3'; ERE2: 5'-ACCCGACCTATTCACCTCAGCCT-3'; ERE3: 5'-GC CGAGTTAAGGTAAATGGCCGC- $3^{\prime}$. Sequence analysis was performed for each construct by Cycle Sequencing (BMR, University of Padova, Italy). 
Experimental animals

Random-bread Swiss CD1 mice were reared in our facilities. All animal experimentation described in this investigation was conducted in accordance with accepted standards of human animal care. All experimental protocols were approved by the local committees on animal care and use, and were in keeping with accepted veterinary medical practice.

Cell culture, treatment, and determination of apoptosis

Primary Sertoli cell cultures were prepared as reported [20]. Tissue explants from 7- or 17-day-old Swiss-CD1 mice were cultured at $32{ }^{\circ} \mathrm{C}$ in serum-free minimum essential medium (MEM; Invitrogen Ltd, Paisley, UK) for 3 days, and then were treated with hypotonic solution (20 mM Tris- $\mathrm{HCl}, \mathrm{pH} 7.5)$ to remove remaining germ cells.

Depending on the experimental procedures, primary Sertoli cells were treated with the indicated concentrations of $E_{2}$, related compounds, or AEA. In some experiments, pargyline $(3 \mathrm{mM})$ was added to the culture medium $16 \mathrm{~h}$ before the treatment with any other substance in order to inhibit LSD1 activity [21].

Apoptotic cell death was quantified after 24-h treatment by ELISA assay (Roche Diagnostics, Mannheim, Germany) based on the evaluation of DNA fragmentation through an immunoassay for histone-associated DNA fragments in the cell cytoplasm. Specific determination of mono- and oligonucleosomes in the cytoplasmic fraction of cell lysates was performed by measuring the absorbance values at $405 \mathrm{~nm}$.

\section{Luciferase assay}

The Sertoli cells were transiently transfected in 96-well plates using Lipofectamine 2000 (Invitrogen, Carlsbad, CA, USA) according to the manufacturer's protocol. The cells were transfected with $200 \mathrm{ng}$ of DNA, containing a mixture of $196 \mathrm{ng}$ of faah promoter constructs and $4 \mathrm{ng}$ of Renilla luciferase reporter gene. After $4 \mathrm{~h}$, cells were washed and cultured in fresh media for $24 \mathrm{~h}$. The cells were then treated for $30 \mathrm{~min}$ in media containing or not containing $\mathrm{E}_{2}$ and ER antagonist. The luciferase activity was quantified using a commercially available kit (dualluciferase reporter assay system; Promega Corp.) with a Perkin-Elmer Victor2 luminometer.

Gene silencing with small interfering RNAs (siRNAs)

Synthetic ready-to-use small (21 nucleotides) interfering RNA (siRNA), complementary to a region of $l s d l$ or $f a a h$, and non-silencing control siRNAs were custom-synthesized by Qiagen (Tokyo, Japan).

To knock-down $l s d l$ gene, Sertoli cells were transfected in 96-well plates with 5 pmol of siRNA and $0.25 \mu \mathrm{l}$ of Lipofectamine 2000 (Invitrogen Ltd) in $50 \mu \mathrm{l}$ of OptiMEM, according to the manufacturer's instructions. After $4 \mathrm{~h}$, cells were washed and cultured in fresh media for $24 \mathrm{~h}$, and then they were transfected with the faah promoter construct and Renilla luciferase reporter gene, as described above.

For faah gene silencing, Sertoli cells were transfected with 600 pmol of siRNA using Lipofectamine 2000 (Invitrogen, Carlsbad, CA, USA), under the same experimental conditions used to knock-down $l s d l$. After $4 \mathrm{~h}$, cells were washed and cultured in fresh media for $24 \mathrm{~h}$. Then, they were cultured for a further $24 \mathrm{~h}$ in media containing AEA $(1 \mu \mathrm{M})$ and $\beta$-estradiol (200 $\mathrm{nM})$, and finally qRT-PCR analysis and evaluation of cell death were performed.

Western blotting and immunofluorescence

Western blotting was performed on Sertoli cell extracts, as described previously [16]. Briefly, cell lysates were separated using SDS-PAGE and electrophoretically transferred to a polyvinylidene difluoride membrane. Membranes were blocked in Tris-buffered saline with $5 \%$ milk and $0.05 \%$ Tween 20, and were probed with primary antibodies at $4{ }^{\circ} \mathrm{C}$ overnight. Appropriate horseradish peroxidase-conjugated secondary antibodies (Jackson ImmunoResearch, West Grove, PA) were used for detection with the ECL and ECL-plus systems (GE Healthcare, Little Chalfont, UK). For immunofluorescence experiments, mouse Sertoli cells were fixed in $4 \%$ paraformaldehyde (PFA) and washed with phosphate-buffered saline (PBS). Samples were permeabilized with $0.1 \%$ Triton $\mathrm{X}-100$ for $5 \mathrm{~min}$ and incubated for $1 \mathrm{~h}$ in $0.5 \%$ bovine serum albumin (BSA). Samples were then washed with PBS and incubated for $2 \mathrm{~h}$ at room temperature with antibodies against LSD1 (1:300) and WT1 (Abcam), followed by $1 \mathrm{~h}$ of incubation with Alexa Fluor 488 goat anti-rabbit (1:300; Invitrogen) and Alexa Fluor 555 goat anti-mouse (1:300; Invitrogen) [8].

Images were taken from a Leica DMI 6000B deconvolution microscope using an HCX PL Fluotar $63 \times 1.25$ oil objective. Images were acquired at room temperature using a Leica DFC 350 FX camera and the Leica Las AF application suite v1.8.0 software. Images were exported as RGB 8-bit TIFF files, and Photoshop and Illustrator programs (Adobe, San Jose, CA) were used for composing the panels.

Chromatin immunoprecipitation

Proteins from Sertoli cells cultured for $60 \mathrm{~min}$ in the presence or absence of $E_{2}$, were cross-linked to DNA by 
direct addition to the culture medium of formaldehyde at a $1 \%$ final concentration for $15 \mathrm{~min}$ at $37^{\circ} \mathrm{C}$. Cells were lysed to isolate nuclei in a hypotonic buffer containing $5 \mathrm{mM}$ PIPES ( $\mathrm{pH} 8.0), 85 \mathrm{mM} \mathrm{KCl}$, and $0.5 \% \mathrm{NP} 40$. Nuclei were then resuspended, lysed in a buffer containing $1 \%$ SDS, $10 \mathrm{mM}$ EDTA, and $50 \mathrm{mM}$ Tris- $\mathrm{HCl}$ (pH 8.0), and sonicated to obtain fragmented chromatin samples, which were immunoprecipitated overnight with $2-4 \mu$ of anti-ER $\beta$ (Santa Cruz Biotechnology, Santa Cruz, CA, USA), anti-LSD1 (Abcam, Cambridge, MA, USA) or antiH3K9me3 (Millipore, Billerica, MA) antibodies, or of rabbit IgGs as a control (Sigma-Aldrich, St. Louis, MO, USA). The protein-DNA complexes were incubated at $65^{\circ} \mathrm{C}$ overnight to reverse protein-DNA crosslinks and precipitated DNA was analyzed by quantitative real-time PCR using 1-5 $\mu \mathrm{l}$ aliquots out of $30 \mu \mathrm{l}$ of DNA. The primers used were the following: for ERE $2 / 3$, forward $\left(5^{\prime}\right.$-TGATGCTGAGACGTTGATAAGG- $\left.{ }^{\prime}\right)$ and reverse (5'-TCGTCTGTTCCGCCTGCCTTAAAA-3'); for distal sequence $(-1,630 /-1,430)$, forward $\left(5^{\prime}\right.$-CCATGGCCTG CTTTCTAAGACTCT- $\left.3^{\prime}\right)$ and reverse (5'-TCCACACCA GACTTAATCAGCC-3'). PCR amplification was performed using Power SYBR Green qPCR SuperMix-UDG with ROX (Invitrogen) in a PRISM 7900 Sequence Detection System (Applied Biosystems, Foster City, CA).

\section{Quantitative real-time PCR}

RNA was extracted from Sertoli cells using the RNeasy extraction kit (Qiagen, Crawley, UK). Quantitative realtime (qRT) PCR reactions were performed using the SuperScript III Platinum Two-Step qRT-PCR Kit (Invitrogen Ltd). Briefly, $1 \mu \mathrm{g}$ of total RNA was used to produce cDNA with $10 \mathrm{U} / \mu 1$ SuperScript III reverse transcriptase, in the presence of $2 \mathrm{U} / \mu \mathrm{l}$ RNaseOUT, $1.25 \mu \mathrm{M}$ oligo $(\mathrm{dT})_{20}, 1.25 \mathrm{ng} / \mu \mathrm{l}$ random hexamers, $5 \mathrm{mM} \mathrm{MgCl}_{2}$, $0.5 \mathrm{mM}$ dNTP mix, and diethyl pyrocarbonate-treated water. The reaction was performed using the following RT-PCR program: $25{ }^{\circ} \mathrm{C}$ for $10 \mathrm{~min}, 42^{\circ} \mathrm{C}$ for $50 \mathrm{~min}$, $85^{\circ} \mathrm{C}$ for $5 \mathrm{~min}$, then after addition of $0.1 \mathrm{U} / \mu \mathrm{l}$ of Escherichia coli $\mathrm{RNase} \mathrm{H}$, the product was incubated at $37^{\circ} \mathrm{C}$ for $20 \mathrm{~min}$. The target transcripts were amplified by means of an ABI PRISM 7700 sequence detector system (Applied Biosystems, Carlsbad, CA, USA), using the following primers (Invitrogen): mouse faah $\mathrm{F}$ (5'-AGATTGAGATG TATCGCCAG- $3^{\prime}$ ), and R (5'-CTTCAGAATGTTGTCCC AC- $\left.3^{\prime}\right)$; mouse LSD1 F ( $5^{\prime}$-TGGGCCCGGGGCTCCTA TTC- $\left.3^{\prime}\right)$, and R ( $5^{\prime}$-GGGATTGGCTGTGGGGCACC- $3^{\prime}$ ); mouse $\beta$-actin $\mathrm{F}\left(5^{\prime}\right.$-TGTTACCAACTGGGACGA- $\left.3^{\prime}\right)$, and $\mathrm{R}$ (5'-GTCTCAAACATGATCTGGGTC- $\left.{ }^{\prime}\right)$. $\beta$-Actin was used as housekeeping gene for quantity normalization. One microliter of the first strand of cDNA product was used (in
Fig. 1 Estrogen stimulation of faah expression. a faah mRNA expression was significantly stimulated by $E_{2}$. Real-time PCR analysis of faah expression in Sertoli cells from 17-day-old mice after treatment with different concentrations of $E_{2}$ for $4 \mathrm{~h}$ as indicated. ***Denotes $p<0.001$ versus Ctrl; **denotes $p<0.01$ versus Ctrl. b Left histogram of luciferase activity in Sertoli cells transiently transfected with pGL3-FAAH or with the promoterless pGL3 plasmid. Luciferase activity is expressed as fold increase over the control vector. Right histogram of luciferase activity in Sertoli cells transiently transfected with pGL3-FAAH $-723 /+10$ or with reporter construct containing three copies of consensus ERE (ERELuc), in the presence or not of $200 \mathrm{nM} \mathrm{E}$ for $30 \mathrm{~min}$. Luciferase activity is expressed as fold increase over the untreated control cells. ***Denotes $p<0.001$ versus Ctrl; **denotes $p<0.01$ versus pGL3. c Luciferase activity in Sertoli cells transiently transfected with pGL3-FAAH $-723 /+10$ after treatment with different concentrations of $\mathrm{E}_{2}$ for $30 \mathrm{~min}$. *denotes $p<0.05$ versus $\mathrm{Ctrl}$; **denotes $p<0.01$ versus Ctrl; $* * *$ denotes $p<0.001$ versus Ctrl. d Effects of epiE 2 , TMX and ICI 182780 (all used at $200 \mathrm{nM}$ ) on $\mathrm{E}_{2}$-dependent transcriptional activation in Sertoli cells. These cells were transfected with Faah $-723 /+10$ or with ERE-Luc and, after $18 \mathrm{~h}$, they were treated with epiE 2 , TMX or ICI 182780 in the presence or absence of $200 \mathrm{nM}$ $\mathrm{E}_{2}$. For FAAH $-723 /+10$ : $* * *$ denotes $p<0.001$ versus Ctrl; *denotes $p<0.05$ versus Ctrl; ${ }^{\# \#}$ denotes $p<0.001$ versus $\mathrm{E}_{2}$; for ERE-Luc: $\$ \$$ denotes $p<0.001$ versus $\mathrm{Ctrl}$; $\$ \$$ denotes $p<0.01$ versus ctrl; ${ }^{\$}$ denotes $p<0.05$ versus Ctrl; ${ }^{\& \& \&}$ denotes $p<0.001$ versus $\mathrm{E}_{2}$

triplicate) for amplification in $25 \mu$ l of reaction solution containing $12.5 \mu \mathrm{l}$ of Platinum SYBR Green qPCR SuperMix-UDG (Invitrogen) and 10 pmol of each primer. The following PCR program was used: $95{ }^{\circ} \mathrm{C}$ for $10 \mathrm{~min}$; 40 amplification cycles at $95{ }^{\circ} \mathrm{C}$ for $30 \mathrm{~s}, 56^{\circ} \mathrm{C}$ for $30 \mathrm{~s}$, and $72{ }^{\circ} \mathrm{C}$ for $30 \mathrm{~s}$.

Bisulfite DNA modification and methylation-specific PCR

Genomic DNA was isolated from Sertoli cells using the DNeasy kit (Qiagen, Crawley, UK). After DNA extraction, $2 \mu \mathrm{g}$ of DNA was treated with bisulfite, using the MethylDetector Bisulfite modification Kit (Active Motif, La Hulpe, Belgium) according to the manufacturer's protocol. PCR analysis was performed as previously described [22]. Two microliters of bisulfite-modified DNA was amplified by using PCR master mix (Promega Corporation, Madison, WI, USA) containing $25 \mathrm{U} / \mathrm{ml}$ of TaqDNA polymerase, $400 \mu \mathrm{M}$ dNTPs, $1.5 \mathrm{mM} \mathrm{MgCl}_{2}$, and $0.4 \mu \mathrm{M}$ of each primer. The amplification program was as follows: $95^{\circ} \mathrm{C}$ for $5 \mathrm{~min} ; 35$ cycles at $95{ }^{\circ} \mathrm{C}$ for $30 \mathrm{~s}, 55^{\circ} \mathrm{C}$ for $30 \mathrm{~s}, 72{ }^{\circ} \mathrm{C}$ for $30 \mathrm{~s}$, and a final extension at $72{ }^{\circ} \mathrm{C}$ for $5 \mathrm{~min}$. The primers used for FAAH promoter amplification (M: methylation specific, U: specific for unmethylated sequence) were the following: faahP MF (5'-TAGAGTTAGGAAAAATGAT GTTGAGAC- $\left.3^{\prime}\right)$, faahP MR (5'-TTTTAAAACAAACGA AACAAACGA-3'), faahP UF (5'-TTAGAGTTAGGAAA AATGATGTTGAGAT- $3^{\prime}$ ), faahP UR (5'-TTTTAAAAC AAACAAAACAAACAAA- $\left.3^{\prime}\right)$, and $\beta$-actin F (5'-TGTT 

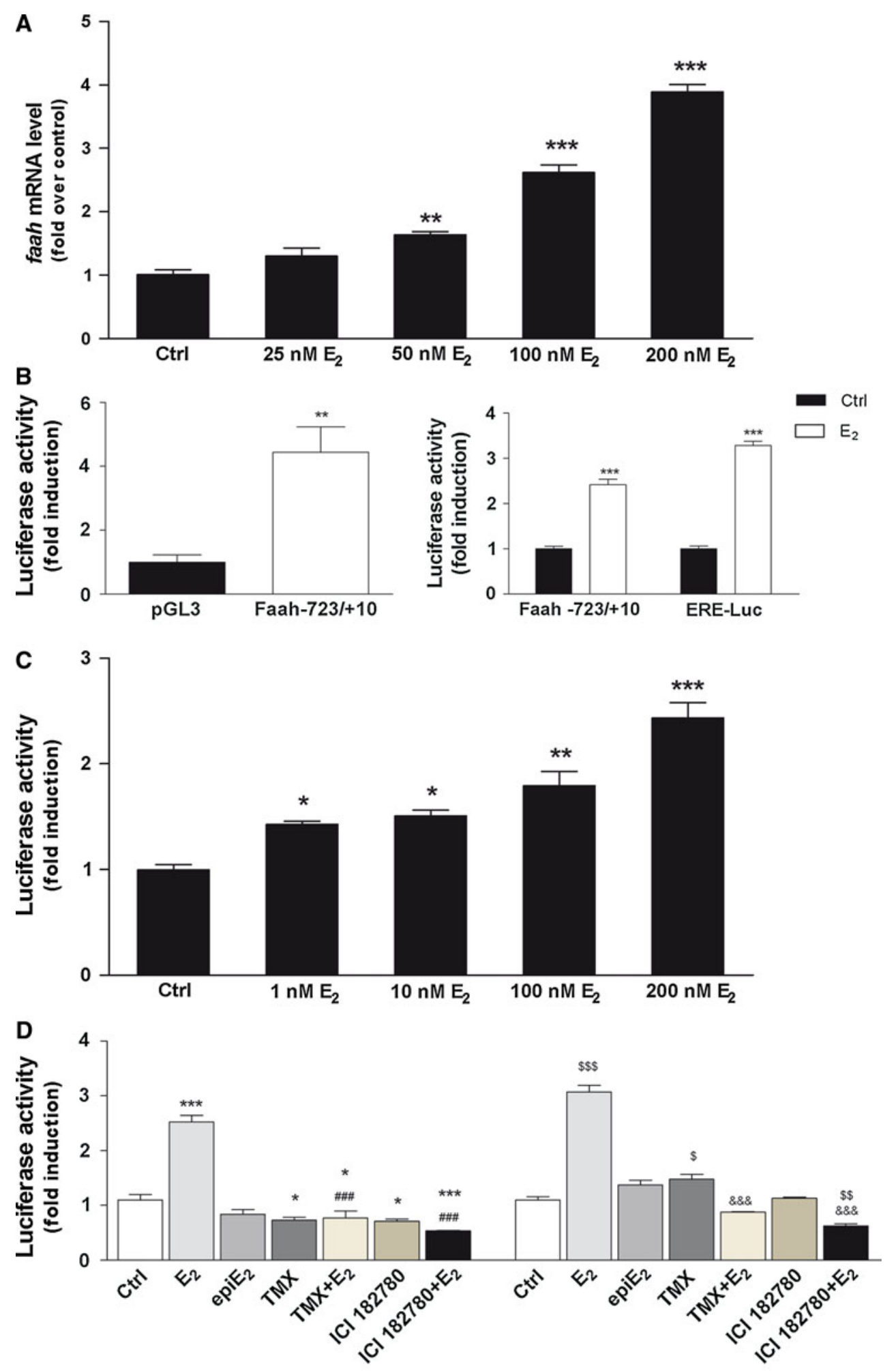

Faah-723/+10

ERE-Luc 
ACCAACTGGGACGA- $\left.3^{\prime}\right), \beta$-actin $\mathrm{R}$ ( $5^{\prime}$-GTCTCAAAC ATGATCTGGGTC- $3^{\prime}$ ). PCR products were loaded on a $1.8 \%$ agarose gel containing ethidium bromide, and were visualized under UV illumination.

\section{Statistical analysis}

The data reported in this study are the mean \pm SEM of at least three independent determinations, each performed in duplicate. Statistical analysis was performed by the nonparametric Student's $t$ test and ANOVA test followed, when necessary, by post hoc Newman-Keuls test (GraphPad Software for Science, San Diego, CA, USA).

\section{Results}

The proximal $5^{\prime}$ flanking region of faah gene is activated by $\mathrm{E}_{2}$

To determine whether the expression of FAAH mRNA was regulated by $E_{2}$ in mouse Sertoli cells, we treated primary cell cultures with different doses of $\mathrm{E}_{2}$ for $4 \mathrm{~h}$. mRNA expression, evaluated by qRT-PCR (Fig. 1a), increased significantly at $50 \mathrm{nM} \mathrm{E}_{2}$ and reached a maximum fourfold increase at $200 \mathrm{nM} \mathrm{E}_{2}$.

In order to study the transcriptional regulation of FAAH, we cloned the $5^{\prime}$ flanking proximal region of the faah gene, $-723 \mathrm{bp}$ to $+10 \mathrm{nt}$ with respect to the translational start site (atg), upstream of the luciferase reporter gene in pGL3 basic vector, and we transiently transfected Sertoli cells. Our construct showed a basal activity three- to fourfold higher than the promoterless vector (Fig. 1b, left panel), indicating that elements responsible for the basal expression of FAAH were present in this region. Then, we observed that treatment with $200 \mathrm{nM} \mathrm{E}_{2}$ stimulated luciferase activity by $\sim 3$-fold (Fig. 1b, right panel), thus suggesting that ERE sequences in the proximal promoter could mediate $E_{2}$ effects. As positive control, we transfected the cells with pERE-luc plasmid containing three ERE consensus sequences upstream of the luciferase gene. In Fig. 1c we show that $E_{2}$ was able to significantly increase faah proximal promoter activity in a dose-dependent manner. Lower concentrations of $E_{2}(1-10 \mathrm{nM})$ had already a significant effect on luciferase activity, but the maximum increase was observed at the highest $(200 \mathrm{nM})$ $\mathrm{E}_{2}$ concentration (Fig. 1c). Thus, the latter dose was used in further experiments. Incidentally, it should be noted that concentrations in the high-nM range have been largely used to investigate gene transcriptional regulation by $E_{2}$ [23-27] or metabolic effect of this hormone [28]. Moreover, it has been shown that intratesticular concentrations are much higher than serum levels of $E_{2}$ [29].
The specificity of $E_{2}$-dependent FAAH transcription was assessed by using $17-\alpha$-estradiol (epiE $E_{2}$ ), which is an epimer of $E_{2}$ unable to bind ER, or specific ER antagonists such as tamoxifen (TMX) and Fulvestrant (ICI 182780) [28]. Sertoli cells were transfected with plasmid FAAH $-723 /+10$ and were then treated with these substances. Figure 1d shows that epiE $E_{2}$ had no effect on promoter activity, and so did TMX and ICI 182780 alone; instead, both ER antagonists abolished the $\mathrm{E}_{2}$-induced luciferase activity, suggesting that $\mathrm{E}_{2}$ regulation of the faah gene was mainly mediated through a canonical estrogen receptor signaling.

Sequence analysis of the proximal $5^{\prime}$ flanking region of the faah gene showed the presence of three potential estrogen receptor-binding sites that were named ERE1 (-614), ERE2 (-381), and ERE3 (-301) (Fig. 2a). Although the proximal promoter did not contain palindromic ERE consensus sequences (GGTCA nnn TGACC), all three EREs contain a well-conserved half-ERE $5^{\prime}$-TG ACC- $3^{\prime}$ or $5^{\prime}$-GGTCA- $3^{\prime}$ core motif. A series of mutants of the proximal promoter were generated to investigate the role of these ERE sites in transcriptional activation by $\mathrm{E}_{2}$ (Fig. 2b). Deletion of the promoter until $-560 \mathrm{nt}$ from the translational start site, which determined loss of the ERE1 site, caused a significant decrease $(\sim 50 \%)$ of promoter stimulation by $E_{2}$ (Fig. 2c). By contrast, deletion of the promoter until nucleotide -250 , that eliminates all ERE sequences, determined a complete loss of $\mathrm{E}_{2}$ inducibility, still maintaining promoter basal activity (Fig. 2c). Moreover, the introduction of site-specific mutations showed that mutation in ERE1 site (TGACCC mutated to TTACAC) still maintained $\mathrm{E}_{2}$ transcriptional activation, but reduced by $\sim 50 \%$, while mutations in ERE2 (ATCTGTTCTGACC mutated to ACCTGTTCACCTC) or ERE3 sequences (GGTCAAGGAAACC mutated to AGTTAAGGCTTAC) completely abolished gene activation by $\mathrm{E}_{2}$ (Fig. 2c). These observations indicate that ERE2 and ERE3 are responsible for faah gene regulation by $\mathrm{E}_{2}$ in Sertoli cells, while ERE1 is required to enhance the transcriptional response.

$\mathrm{E}_{2}$ induces $\mathrm{ER} \beta$ binding to ERE $2 / 3$ sites in the proximal promoter and activation of histone demethylase LSD1

To assess whether $\operatorname{ER} \beta$ associated in vivo with the ERE sites in the faah proximal promoter, genomic DNA from Sertoli cells obtained from 17-day-old mice and treated or not with $\mathrm{E}_{2}$ was subjected to chromatin immunoprecipitation (ChIP) assays, using anti-ER $\beta$ antibodies followed by qRT-PCR. $\mathrm{E}_{2}$ treatment determined a $\sim 2.5$-fold increase of ERE2/3 DNA (region a) immunoprecipitated with anti$\operatorname{ER} \beta$ antibodies (Fig. 3a), indicating that $\operatorname{ER} \beta$ was associated with the ERE2/3 sequences in a ligand-dependent manner. Instead, the receptor was not associated with a $5^{\prime}$ 
Fig. 2 ERE-binding sites in the faah proximal promoter are required for activation by $\mathrm{E}_{2}$. a Nucleotide sequence of the proximal $5^{\prime}$ flanking region of the mouse faah gene from -723 to $+13 \mathrm{nt}$ from the translational start site. faah sequence from -723 to +10 was PCR amplified using primers reported in "Materials and methods" and Ref. [45]. Putative ERE sites are underlined and indicated as ERE1-3. The translational start codon (atg) is in bold.

b Schematic representation of faah promoter $5^{\prime}$ sequential deletion constructs and sitespecific mutants at ERE1, ERE2, or ERE3 sites. Half ERE sites are indicated. c Sertoli cells were transfected with $0.2 \mu \mathrm{g}$ of each faah promoter construct, and were treated or not with $200 \mathrm{nM} \mathrm{E}_{2}$ for $30 \mathrm{~min}$. After incubation, dual-luciferase reporter assays were performed. ***Denotes $p<0.001$ versus Ctrl; **denotes $p<0.01$ versus Ctrl; *denotes $p<0.05$ versus Ctrl
A -760 caccagtgtg actccaaaa gtcatttaac ccttcttgtc ctgaagttac ctcactagta -700 aagtgcaaaa tgccttctc acaggatttc tagatggatg agatgagtcg cataaattc -640 tgtgacagca atctagccac aattagggtg tgcatgaccc taatttacgc cgccccettc -520 agagaggatg agctgtgggg atgaggaaa agacgtaggt agatagccca gagtaaagg -490 ctcaacatct ggagggtggg tagaaaatga gaggccacac ctcagaactt cctgcagtcc -430 agagccagga aaatgatgc tgagacgttg ataaggttca ctgcacccga tctgttctga -370 ccagcctgtt ctgaggaccc tggcttagcc cagttttcgg ctgtagggcg gagacgaagc -310 cagaggccgg gtcaaggaaa ccggccgecc tggtgctttg gagggcgecc acgeggagct -250 cgtctgttcc gcctgcctta aaacgctggc acgccaggaa ccgggccaga aggggtctag -190 gettgacett gaccgttgga getgctagct tggctctcgc tgccgggcaa cggcgcgctc -130 cccgcgggcc cgcggetgcg cctgcccetc cetcaagcgg aatcgcgggc gatccaggcc - 70 gggttttgca gcggagctgt tggtgtgcgc gtgccgagtc ctctcgggtg gcggtcgget - 10 gcaggagatc atggtgctga gcg

ERE1 ggtg tgcatgaccc ERE2 a tctgttctga CC ERE3 g gtcaaggaaa cC

B

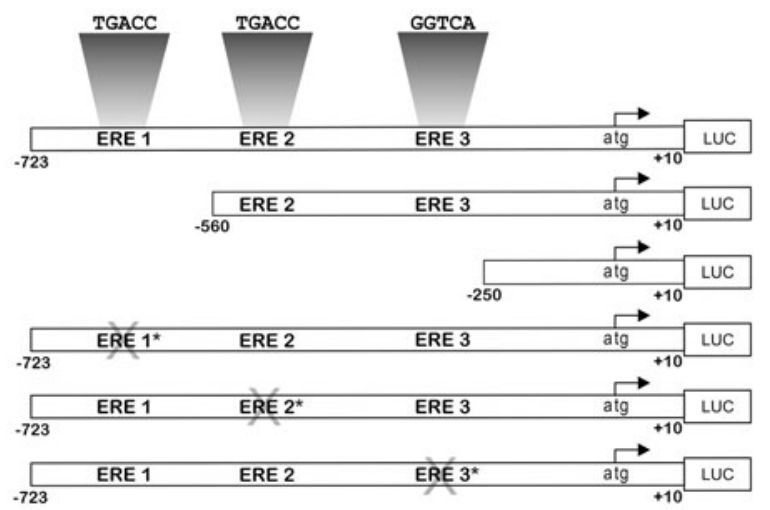

C

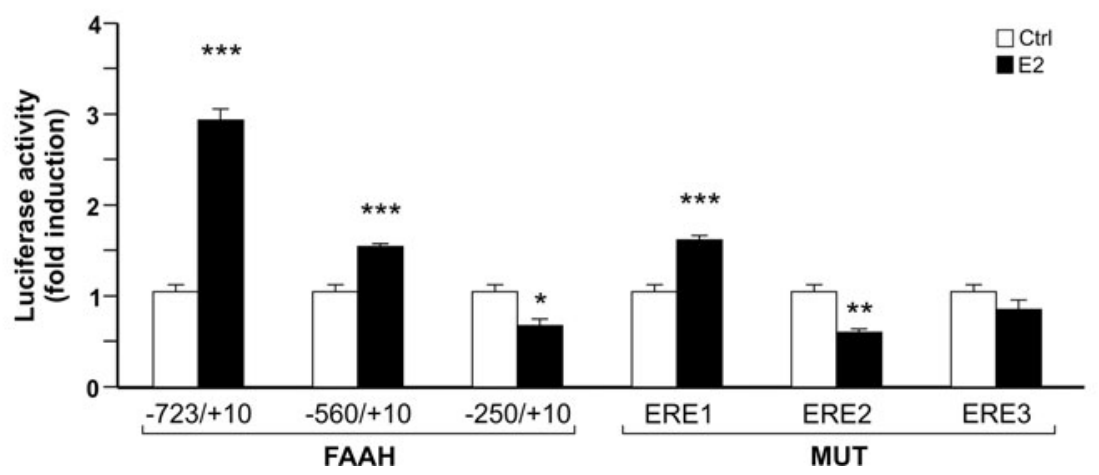

upstream promoter region between $-1,630$ and $-1,430$ from the translational start site (region $b$ ), demonstrating the specificity of the $\operatorname{ER} \beta$ binding to the proximal region of the faah gene (Fig. 3a).

Nuclear hormone receptors are known to activate transcription by recruiting coactivators that can eventually modify chromatin structure and allow the assembly of the RNA PolII transcriptional machinery at the promoter site. More recently, the lysine-specific demethylase 1 (LSD1) has been demonstrated to control nuclear hormone receptor-dependent gene expression, by activating ER target genes [21, 30], as well as androgen-receptor target genes like PSA [31]. On this background, we investigated the role of LSD1 in estrogen-regulated expression of the faah gene in Sertoli cells. By means of qRT-PCR and immunoblotting analyses, we found that Sertoli cells express LSD1 (Fig. 4a, b), and that this enzyme is mainly localized in the nuclear compartment as shown by immunofluorescence (Fig. 4c). To demonstrate the recruitment of LSD1 to the ERE2/3 sites of faah promoter, we performed ChIP analysis using anti-LSD1 antibodies to immunoprecipitate Sertoli cell chromatin. We found that LSD1 was specifically associated with chromatin at ERE2/3 sites and that $\mathrm{E}_{2}$ did not modify its binding (Fig. 3a).

LSD1 is an amine oxidase, and thus its activity can be inhibited by monoamine oxidase inhibitors like pargyline (Parg) [21, 31]. We found that treatment with Parg, as well as knock-down of $l s d l$ gene in Sertoli cells transfected with 
A
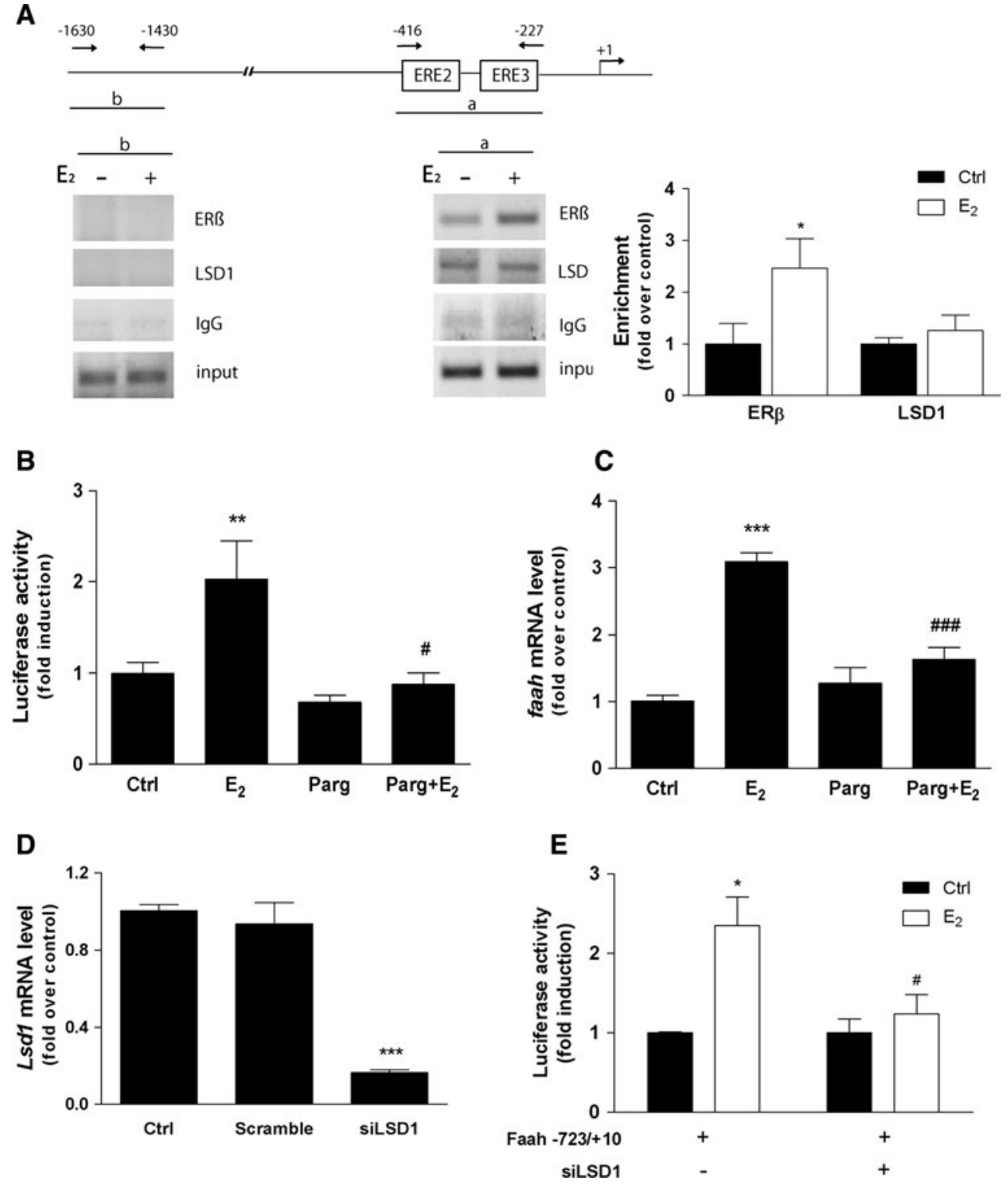

Fig. $3 \mathrm{E}_{2}$ induces $\mathrm{ER} \beta$ binding and LSD1 activation at ERE sites in the faah proximal promoter. a Diagram of mouse faah $5^{\prime}$-flanking region with the location of primers used for ChIP-qPCR in the indicated regions $a$ and $b$. Chromatin immunoprecipitation (ChIP) assays were performed with anti-ER $\beta$ and anti-LSD1 antibodies in Sertoli cells treated or not with $200 \mathrm{nM} \mathrm{E} \mathrm{E}_{2}$ for $1 \mathrm{~h}$, and analyzed by quantitative real-time PCR. A representative agarose gel of PCR products of ERE2/3 region of faah promoter is shown. Input chromatin, indicating sample before immunoprecipitation, and no primary antibody (IgG) were included as positive and negative controls, respectively. Bar graph represents fold enrichment of ER $\beta$ and LSD1 bound to ERE2/3 in $E_{2}$-treated cells relative to that in the control cells. Results were normalized for input and non-immune rabbit $\mathrm{IgG}$, and *denotes $p<0.05$. b Pargyline reduces $\mathrm{E}_{2}$ stimulation

the FAAH $-723 /+10$ plasmid, blocked the $E_{2}$-induced faah promoter activity (Fig. 3b, e). Moreover, Parg abolished $E_{2}$ stimulation of endogenous FAAH expression of faah promoter in Sertoli cells, as analyzed by luciferase assay. Sertoli cells were transfected with FAAH $_{-723 /+10}$, and were treated with $3 \mathrm{mM}$ pargyline for $16 \mathrm{~h}$, and then for 30 min with $200 \mathrm{nM} \mathrm{E} 2$. After incubation, dual-luciferase reporter assays were performed. **Denotes $p<0.01$ versus $\mathrm{Ctrl}$; \#denotes $p<0.05$ versus $\mathrm{E}_{2}$. c Pargyline reduces $\mathrm{E}_{2}$-induced expression of endogenous faah gene in Sertoli cells, analyzed by qRT-PCR. ***Denotes $p<0.001$ versus $\mathrm{Ctrl}$; ${ }^{\# \#}$ denotes $p<0.001$ versus $\mathrm{E}_{2}$. d Sertoli cells were transfected with $l s d 1$ siRNA. Knock-down of endogenous LSD1 was ascertained by qRT-PCR. ***Denotes $p<0.001$ versus Ctrl. e LSD1 silencing reduced $\mathrm{E}_{2}$ stimulation of faah promoter in Sertoli cells, analyzed by luciferase assay. *Denotes $p<0.05$ versus Ctrl; \#denotes $p<0.05$ versus $\mathrm{E}_{2}$

(Fig. 3c). Incidentally, transfection of Sertoli cells with the lsdl siRNA effectively knocked-down the expression of the target gene (Fig. 3d). 
A

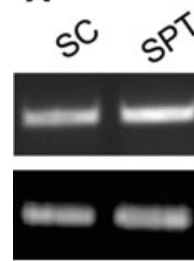

LSD1

actin

C dapi
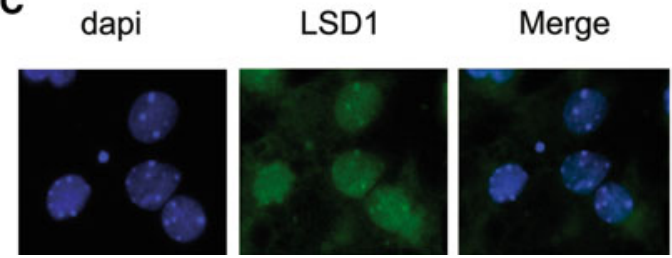

Fig. 4 LSD1 expression in Sertoli cells. a PCR and Western blotting (b) show the expression of LSD1 in Sertoli cells. Spermatids were used as positive controls. c Immunofluorescence shows nuclear localization of LSD1 in Sertoli cells

Altogether, these results indicate the engagement of LSD1 in regulating $\mathrm{E}_{2}$-induced expression of faah gene.

Faah gene expression is not regulated by $\mathrm{E}_{2}$ in immature Sertoli cells

Sertoli cells undergo extensive changes during the postnatal period, and these modifications are critical for the establishment of spermatogenesis and the development of the adult pattern of testicular function. Indeed, it has been demonstrated that FAAH expression and activity in Sertoli cells decrease in an age-dependent manner [14]. To ascertain whether regulation of FAAH expression by $\mathrm{E}_{2}$ was modified during postnatal development, we analyzed by qRT-PCR FAAH mRNA expression in Sertoli cells obtained from 7-day-old mice. We found that FAAH mRNA expression was not stimulated by $E_{2}$ in immature cells, either after $4 \mathrm{~h}$ or after $24 \mathrm{~h}$ of treatment (Fig. 5a). Transfection experiments with FAAH $-723 /+10$ plasmid in immature Sertoli cells confirmed that proximal promoter had basal transcriptional activity, but it was not significantly stimulated by $E_{2}$ (Fig. $5 b$ ). One possible reason for the loss of regulation of faah gene by $\mathrm{E}_{2}$ in immature cells could be the absence of either ER $\beta$ or LSD1, which mediate this activity of $E_{2}$ in the mature (17-day-old) cells. $\operatorname{ER} \beta$ was found to be expressed to a similar protein level at both ages, as analyzed by Western blotting (Fig. 5c), whereas LSD1 was not expressed in immature Sertoli cells, as shown by qRT-PCR (Fig. 5d), immunoblotting (Fig. 5c) and immunofluorescence (Fig. 5e). These results point to the lack of LSD1 as one of the possible causes of the loss of faah promoter inducibility by $\mathrm{E}_{2}$ in immature (7-day-old) versus mature (17-day-old) Sertoli cells.
$E_{2}$ induces epigenetic modifications of the chromatin at $5^{\prime}$ flanking region of the faah gene

DNA methylation and histone methylation are important epigenetic modifications that are strictly related to gene transcription. Actively transcribed genes are typically unmethylated at $\mathrm{CpG}$ islands in the promoter region, and are marked by $\mathrm{H} 3 \mathrm{~K} 9$ hypomethylation. Thus, we investigated the effect of $E_{2}$ on these epigenetic modifications in the faah proximal promoter. DNA methylation was examined by using an MSP-PCR assay, which is sensitive and specific for methylation of any $\mathrm{CpG}$ site located within CpG islands [22] (Fig. 6a). Control Sertoli cells showed a marked methylation of faah promoter (Fig. 6b), consistent with a low expression of this gene, while $\mathrm{E}_{2}$ treatment dramatically decreased the methylation levels of the proximal region, in line with the observed increase of expression levels.

Histone methylation of the faah proximal promoter was investigated in vivo by ChIP assays using antibodies against $\mathrm{H} 3 \mathrm{~K} 9 \mathrm{me} 3$. After $60 \mathrm{~min}$ of $200 \mathrm{nM} \mathrm{E}_{2}$ stimulation, we observed a decrease in $\mathrm{H} 3 \mathrm{~K} 9 \mathrm{me} 3$ levels in ERE2/3 sites (region a) of the faah promoter with respect to untreated cells (Fig. 6c). In order to demonstrate that lower $E_{2}$ doses $(10 \mathrm{nM})$ could be sufficient to induce the same molecular effects observed at $200 \mathrm{nM} \mathrm{E}_{2}$, we investigated the chromatin modifications in the faah proximal promoter by analyzing H3K9 methylation by ChIP assays. We found that $10 \mathrm{nM} \mathrm{E}_{2}$ decreased the $\mathrm{H} 3 \mathrm{~K} 9 \mathrm{me} 3$ level in the ERE2/3 sites (region a) of the faah promoter in Sertoli cells in a similar manner compared to $200 \mathrm{nM} \mathrm{E}_{2}$ (Supplementary Fig. 1 and Fig. 6c). This observation further supports the in vivo physiological relevance of the effects of $\mathrm{E}_{2}$ on faah promoter in mouse Sertoli cells. Altogether, our results indicate that $\mathrm{E}_{2}$ triggers epigenetic modifications in the faah promoter that favor a more transcriptionally competent configuration of chromatin.

FAAH silencing abolishes $\mathrm{E}_{2}$-mediated protection of Sertoli cells against AEA-induced apoptosis

Previous studies have clearly demonstrated the effect of AEA in inducing apoptosis of Sertoli cells, and the crucial role of FAAH in promoting survival of these cells by degrading AEA itself [15]. To provide evidence for the biological relevance of FAAH regulation by $\mathrm{E}_{2}$, we analyzed apoptosis induced by AEA in Sertoli cells, after knocking down the faah gene through siRNA. Figure 7a shows that transfection of Sertoli cells with the FAAH siRNA effectively knocked down the expression of the faah gene, and erased its induction by $\mathrm{E}_{2}$. Furthermore, as reported in Fig. $7 \mathrm{~b}$ the addition of AEA to Sertoli cells for $24 \mathrm{~h}$ significantly increased the extent of apoptosis, 


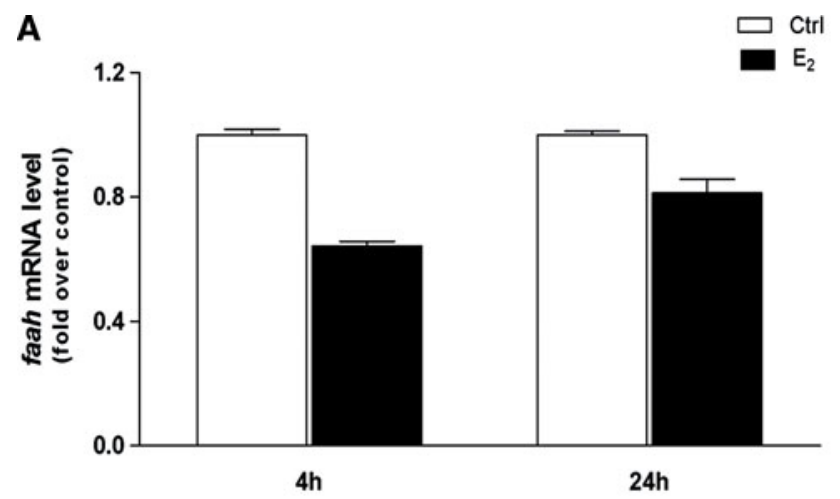

C

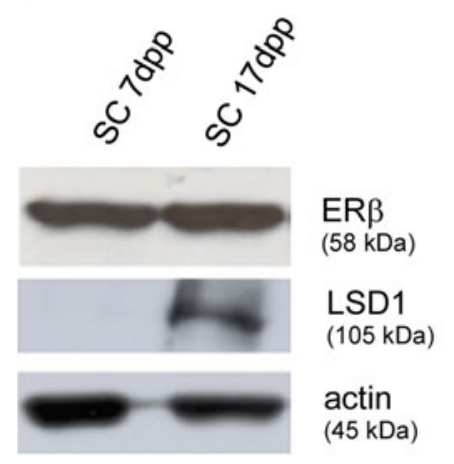

D

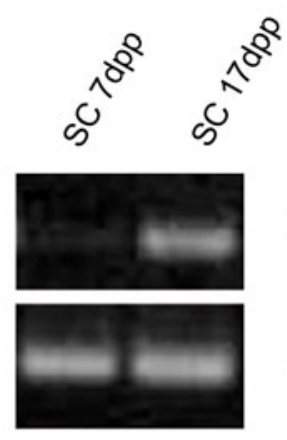

B

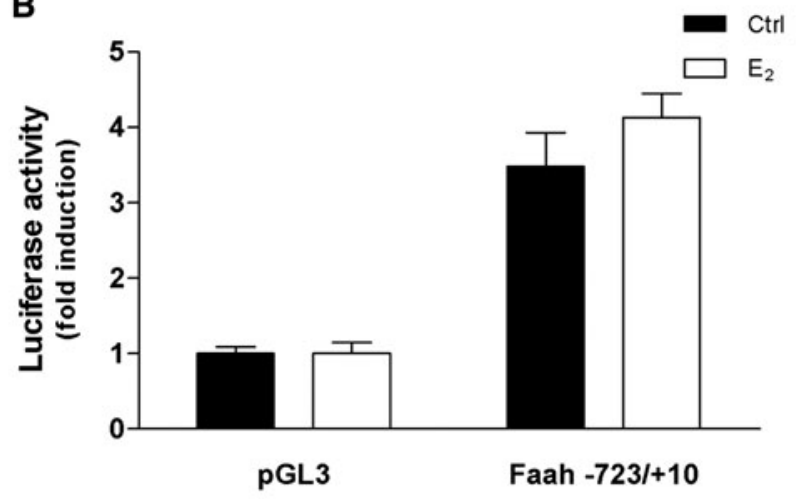

$\mathbf{E}$
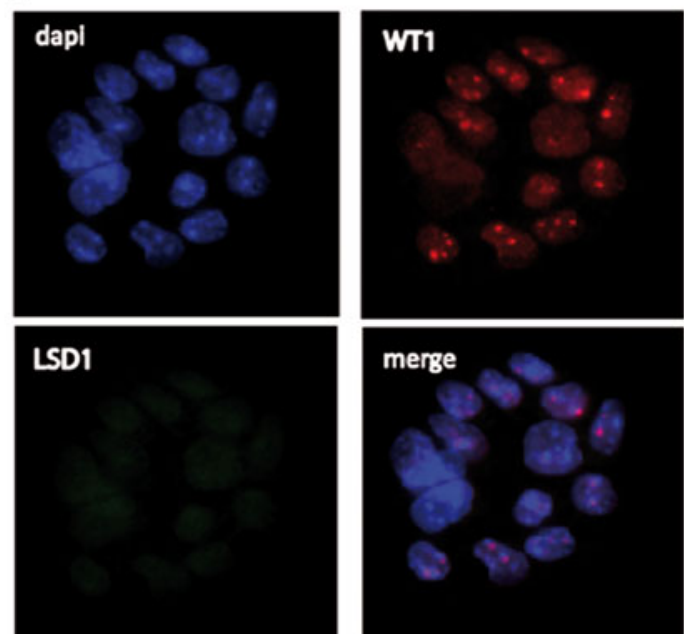

Fig. 5 FAAH is not regulated by $\mathrm{E}_{2}$ in immature Sertoli cells. a Faah mRNA expression was not stimulated by $200 \mathrm{nM} \mathrm{E}_{2}$ in Sertoli cells from 7-day-old mice. Quantitative RT-PCR analysis of faah expression in Sertoli cells from 7-day-old mice after treatment with $200 \mathrm{nM}$ $\mathrm{E}_{2}$ for 4 or $24 \mathrm{~h}$ as indicated. b Sertoli cells were transiently transfected with Faah $-723 /+10$ or with the promoterless pGL3 plasmid, and were stimulated with $\mathrm{E}_{2}$. Luciferase activity is expressed as fold

evaluated as DNA fragmentation [15] and, as expected, the latter process was further increased by FAAH silencing. On the other hand, a strong increase in DNA fragmentation of FAAH-silenced cells was observed upon treatment with a combination of AEA and $E_{2}$ (Fig. 7b).

\section{Discussion}

Many studies have underlined the importance of estrogens in male fertility [5, 32-34], as demonstrated by the expression of ERs and aromatase in the testis and by the fact that mice lacking either ER $\alpha$ [5] or aromatase [6] show altered spermatogenesis and infertility. However, evidence for a direct action of $\mathrm{E}_{2}$ on the seminiferous epithelium is still missing, and remarkably genes that are regulated by $\mathrm{E}_{2}$ through classical ERE sequences remain unknown in the increase over the untreated cells. c, d LSD1 expression in immature Sertoli cells from 7-day-old mice was analyzed by RT-PCR (c) and by Western blotting (d), and was compared to mature (17-day-old) Sertoli cells. e The absence of LSD1 was verified by immunofluorescence analysis of Sertoli cells from testes of 7-day-old mice, using anti-LSD1. Anti-WT1 antibodies were used as Sertoli cell-specific marker

testis. Yet, the latter organ contains all cofactors necessary to directly activate genes in response to $E_{2}$, as demonstrated by using luciferase reporter gene assays under the control of three tandem ERE elements in testis of transgenic mice [35].

Here we demonstrate that the faah gene is the first direct target of $E_{2}$ in Sertoli cells. We show that $E_{2}$ induced a $\sim 4$-fold increase of FAAH mRNA in Sertoli cells and that this stimulation occurred at the transcriptional level. However, we cannot exclude that estrogen might also modulate mRNA stability. In the same context, in our study we found that supraphysiological $(200 \mathrm{nM})$ and physiological (10 $\mathrm{nM}) \mathrm{E}_{2}$ concentrations have the same effects on the molecular mechanisms involved in the stimulation of faah promoter activity; yet, caution should be taken because at higher concentrations, $\mathrm{E}_{2}$ might also have offtarget effects. The proximal $5^{\prime}$ flanking region of the mouse 
Fig. 6 DNA and histone demethylation is induced by $\mathrm{E}_{2}$ at $5^{\prime}$ flanking region of the faah gene. a Schematic representation of the $\mathrm{CpG}$ island identified in the FAAH promoter. ERE sites and localization of primers for PCR amplification are indicated. b Sertoli cells were treated or not with $200 \mathrm{nM} \mathrm{E}_{2}$ for $30 \mathrm{~min}$, and then DNA was extracted and analyzed by PCR, using specific primers as indicated in "Materials and methods". c ChIP assay was performed with anti-H3K9me3 antibody in Sertoli cells treated or not with $200 \mathrm{nM} \mathrm{E}_{2}$ for $1 \mathrm{~h}$, and analyzed by qRT-PCR. A representative agarose gel of PCR products of ERE2/3 sites (region a) of faah promoter is shown. Input chromatin, indicating sample before immunoprecipitation, and no primary antibody (IgG) were included as positive and negative controls, respectively. Bar graph represents fold enrichment of $\mathrm{H} 3 \mathrm{~K} 9 \mathrm{me} 3$ in $\mathrm{E}_{2}$-treated cells relative to controls. Results were normalized for input and non-immune rabbit IgG
A

ERE2

tgacdagcctgttctgaggaccctggcttagcccagttttcggctgtagggcggagacgaagccagaggcc gggtcaaggaaach ggecgecctggtgctt tggagggcgcccacgcggagctcgtctgttccgcctgccttaaaacgctggcacgccaggaaccgggccagaaggggtctaggcttgaccttgaccgttgg agctgctagcttggctctcgctgccgggcaacggcgcgctccccgcgggccegcggctgcgectgcccctccctcaagcggaatcgcgggcgatccaggcc

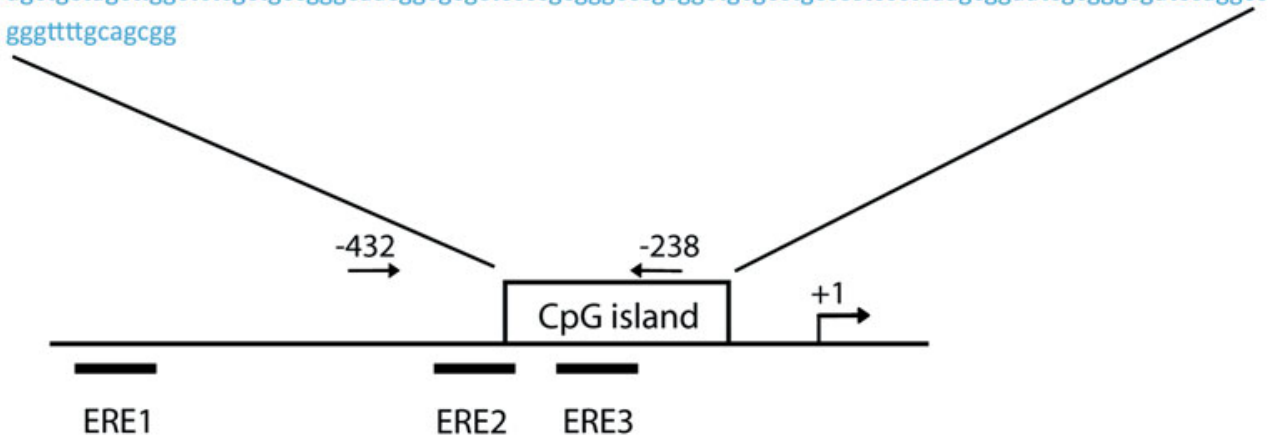

B

C

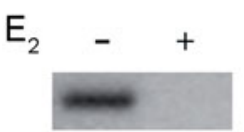

methylated

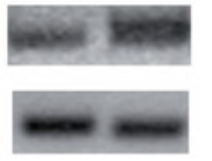

unmethylated

actin

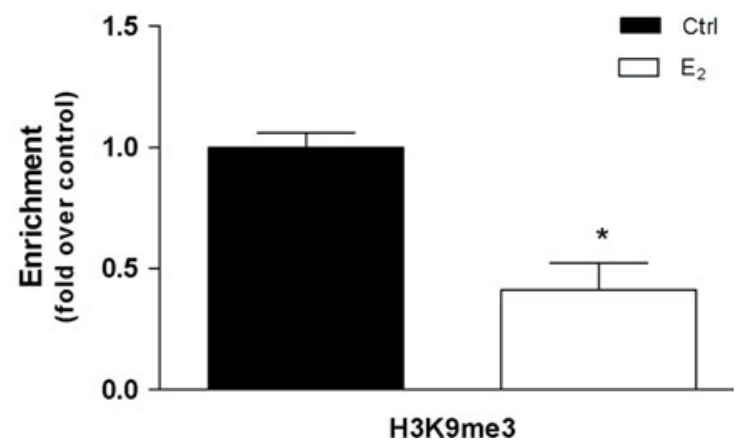

faah gene contained the elements necessary for basal and inducible transcription in Sertoli cells. Through the use of selective estrogen receptor modulators like TMX or ICI 182780 , we demonstrated the specificity of estrogen regulation. In fact, both drugs exhibited a complete antagonist effect on $E_{2}$-mediated stimulation of the FAAH promoter and they did not have any direct effect when given alone. This is in agreement with a previous study reporting that TMX exhibited a pure antagonism in an ER $\beta$ expressing system [36]. Consistently with these data epiE $E_{2}$, which is ineffective at ERs [28, 29], had no effect on FAAH expression. In the proximal promoter, at least three potential ERE sequences can be identified. Two ERE sites, named ERE2 and ERE3, are at a distance of $60 \mathrm{bp}$ from each other, and proximal to the transcriptional start site; the third, ERE1, is located upstream of them, at position -615 from the translational start site. These are all imperfect ERE sites because they do not contain canonical palindromic ERE sequences, yet they show half-ERE consensus sequences. Although it has been reported that half-ERE sites confer weak $\mathrm{E}_{2}$ responsiveness, genes are known for which $\mathrm{E}_{2}$-induced transcription is mediated by two or more ERE half-sites [37]. The importance of these sites in mediating the $\mathrm{E}_{2}$ effect on faah promoter activity has been investigated by mutant analysis, demonstrating that ERE2 and ERE3 are necessary for promoter stimulation by $E_{2}$; indeed, deletion of one of these sites or mutations in their sequence completely abolished the $E_{2}$ effect. Instead, ERE1 is involved in enhancing the $E_{2}$ response of the proximal promoter, since its deletion or mutation caused a reduction of the promoter inducibility.

The biological effects of $E_{2}$ are mediated by $E R \alpha$ and $\operatorname{ER} \beta$ [36], and it has been previously demonstrated that mouse Sertoli cells express only $\operatorname{ER} \beta$ [3]. By using a ChIP assay with Sertoli cells, we examined the ligand-dependent recruitment of $\operatorname{ER} \beta$ to the faah promoter in vivo, and we found that $\mathrm{E}_{2}$ increased $\mathrm{ER} \beta$ binding to $\mathrm{ERE} 2 / 3$ promoter sites. This observation is the first to highlight a functional 
A

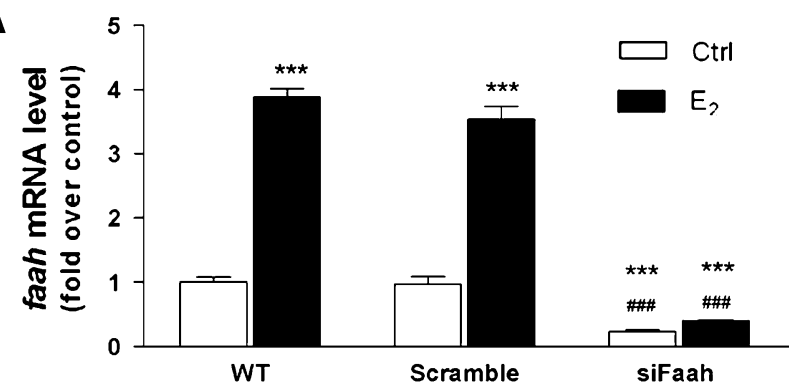

B

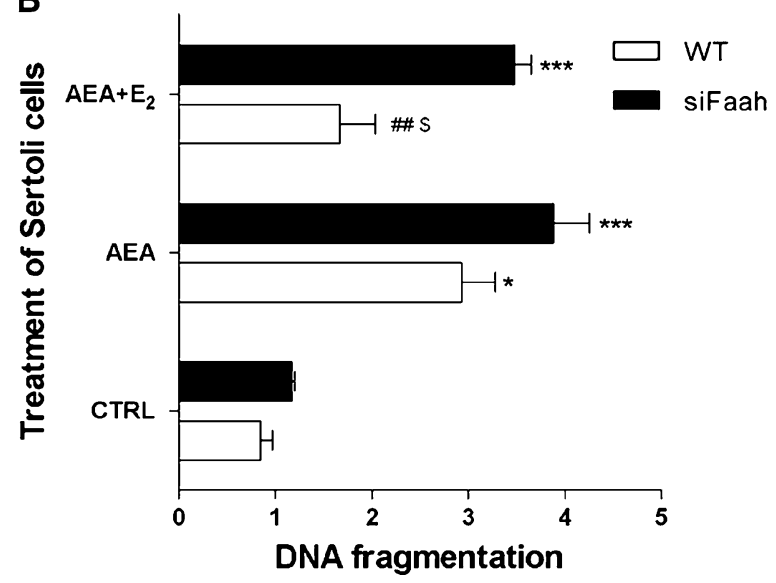

Fig. 7 Faah knockdown increases AEA-induced apoptosis in Sertoli cells. a Sertoli cells were transfected with siRNA faah and stimulated with $200 \mathrm{nM} \mathrm{E}_{2}$ for $24 \mathrm{~h}$. Knockdown of endogenous FAAH was ascertained by qRT-PCR. siFaah abolished $\mathrm{E}_{2}$ induction of faah gene expression. ***Denotes $p<0.001$ versus ctrl; ${ }^{\# \# \#}$ denotes $p<0.001$ versus $E_{2}$. b Effect of FAAH silencing on DNA fragmentation induced by $1 \mu \mathrm{M}$ AEA in Sertoli cells. *Denotes $p<0.05$ versus Ctrl wt; ***denotes $p<0.001$ versus Ctrl wt; ${ }^{\$}$ denotes $p<0.05$ versus AEA wt; ${ }^{\# \#}$ denotes $p<0.01$ versus AEA siFaah

role of $\operatorname{ER} \beta$ in somatic cells of the testis as ligand-activated nuclear transcription factors.

One mechanism by which nuclear hormone receptors can activate transcription is the recruitment of coactivators that can modify chromatin structure and allow the assembly of the RNA PolII transcriptional machinery to the promoter. Recent studies highlight the importance of these chromatin modifications in the transcriptional regulation mediated by nuclear hormone receptors, and suggest that histone modifiers could be nuclear receptor coregulators [38]. LSD1 was identified as the first histone lysine demethylase that acts on either lysine 4 residues (H3K4) or lysine 9 (H3K9) on histone 3 [30, 31] in a contextdependent manner, and acts as a transcriptional inhibitor or activator, respectively. LSD1 contains a SWIRM domain, which functions as a putative protein-protein interaction motif, and an amine oxidase domain that harbors the demethylase activity. Recent evidence demonstrates that LSD1 participates in androgen receptor (AR) and estrogen receptor-dependent gene expression. LSD1 is implicated in
H3K9 demethylation associated with PSA gene activation in an AR-dependent manner [30], and with activation of most ER $\alpha$ gene targets in MCF7 cells [31]. In our study, we show by qRT-PCR and immunoblotting that LSD1 is expressed in Sertoli cells and is recruited in vivo at the ERE2/3 sites of the faah gene both in the presence and in the absence of the ligand. Remarkably, depletion of LSD1 in Sertoli cells by RNAi experiments or inhibition of its activity by pargyline completely abolished stimulation by $\mathrm{E}_{2}$ of FAAH promoter activity. Furthermore, pargyline abolished the $\mathrm{E}_{2}$-induced expression of endogenous FAAH, thus indicating that LSD1 activity is important in $\mathrm{E}_{2}$ transcriptional activation of the faah gene. It has been suggested that LSD1 interacts with different partners, and could act by silencing or activating gene transcription. We speculate that in Sertoli cells LSD1 interacts with ligandbound $\operatorname{ER} \beta$ at ERE sites of target genes, and that this interaction is required for potentially conferring to promoter a transcriptional competence.

In our investigation, we also document that faah proximal promoter is not regulated by $\mathrm{E}_{2}$ in immature proliferating Sertoli cells. We hypothesized that a low level of expression of $\operatorname{ER} \beta$ in immature cells or the absence of LSD1 could account for this lack of effect. Interestingly, we found that immature cells express $\operatorname{ER} \beta$ at the same level as mature cells, but they do not express LSD1. Thus, we suggest that the absence of the latter histone demethylase could contribute to the loss of $E_{2}$ inducibility of FAAH promoter at this age. In mammary tumor cell lines it has been demonstrated that ER $\alpha$ binding to target regulatory sequences is impaired by DNA hypermethylation of CpGs, and that the first step needed to stimulate $\mathrm{E}_{2}$-regulated gene expression is to eliminate epigenetic barriers, thus allowing $\mathrm{ER} \alpha$ access to regulatory sequences [39]. DNA cytosine methyltransferase 1 (DNMT1) is the most abundant and catalytically active DNA methyltransferase, and is able to induce covalent addition of a methyl group to the $5^{\prime}$ position of cytosine, predominantly within $\mathrm{CpG}$ dinucleotides, which are generally localized in promoter regions [40]. More recently, the interaction between DNMT1 and $\operatorname{ER} \beta$ has been demonstrated in the testis, suggesting that $E_{2}$ signaling could control DNA methylation [8]. On this background, we analyzed the DNA methylation in the faah promoter and we observed a dramatic demethylation of the $\mathrm{CpG}$ island located in the proximal region after $\mathrm{E}_{2}$ treatment.

In addition, it has been reported that demethylation of histone 3 at lysine 9 is an important mark associated with transcriptional activation [30]. Here, we document that $\mathrm{E}_{2}$-stimulated transcription of faah gene is accompanied by a decline in $\mathrm{H} 3 \mathrm{~K} 9 \mathrm{me} 3$ at the ERE2/3 sites, suggesting indeed a role for these modifications in the transcriptional activation of faah promoter by $\mathrm{E}_{2}$. In light of this observation, it is 
possible to speculate that $\mathrm{E}_{2}$-induced expression of the faah gene might require, in addition to LSD1, the recruitment of other histone methylases (HMTs) and demethylases (HDMs) in order to promote gene transcription.

Recent data suggest that specific gene regulation requires the assembly and coordinate action of HMTs and HDMs with distinct substrate specificities. Wissmann and colleagues [41] have demonstrated that JMJD2C, which demethylases $\mathrm{H} 3 \mathrm{~K} 9 \mathrm{me} 3$, and LSD1, which specifically demethylases $\mathrm{H} 3 \mathrm{~K} 9$ me2/me1, interact and cooperatively stimulate AR-dependent gene transcription. Recently it has been also reported, in ER $\alpha$ regulated transcription, a coordinated interaction among $\mathrm{ER} \alpha$ and the H3K9me3 demethylase JMJD2B, and the H3K4 methyltransferase MLL2 complex has been recently reported [42]. Previous studies have underlined the importance of FAAH in male fertility [18, 43], where this hydrolase controls the endogenous levels of AEA, and hence its signaling. For instance, high levels of AEA adversely affect sperm motility, capacitation and acrosome reaction [17, 18], and reduce spermatogenic output by inducing Sertoli cell apoptosis [15]. In line with this, genetic loss of FAAH in mouse leads to elevated levels of AEA in the male reproductive tissues, thus impairing sperm fertilizing capacity [43]. In the testis, Sertoli cells play a crucial role in supporting and regulating germ cell development, and their number is strictly correlated with sperm production [44]. It is also well documented that germ cell apoptosis is physiologically required for the maintenance of an optimal ratio of germ cells to Sertoli cells in the seminiferous epithelium. In this context, it should be recalled that after a first wave of prepuberal cell division, Sertoli cells stop dividing and their number remains constant through the lifespan. Keeping this in mind, we can speculate that the control of Sertoli cell apoptosis could be important to maintain their population size, and consequently, to sustain a normal spermatogenic output. Therefore our findings, showing that $\mathrm{E}_{2}$ can protect Sertoli cells against AEAinduced apoptosis via activation of faah gene expression, suggest that $E_{2}$ could be a pro-survival hormone for Sertoli cells.

In conclusion, in this investigation we have identified FAAH as the first direct target gene of $E_{2}$ in Sertoli cells, showing that enhancement of faah promoter activity engages ER $\beta$ and histone demethylase LSD1 and requires chromatin configuration competent for transcription. These findings support an unprecedented role for $\mathrm{E}_{2}$ as pro-survival hormone for Sertoli cells, with a clear impact on spermatogenesis. They also call for further studies on the cross-talks between steroid hormones and endocannabinoids that might orchestrate signaling pathways well beyond reproductive organs.
Acknowledgments We thank Dr. Claudio Sette (University of Rome "Tor Vergata") for critically reading the manuscript. This work was supported by Grants from Agenzia Spaziale Italiana to RG and MM, and from Fondazione TERCAS (2009-2012 project) to MM.

\section{References}

1. O’Donnell L, Robertson KM, Jones ME, Simpson ER (2001) Estrogen and spermatogenesis. Endocr Rev 22:289-318

2. Mangelsdorf DJ, Thummel C, Beato M, Herrlich P, Schütz G, Umesono K, Blumberg B, Kastner P, Mark M, Chambon P, Evans RM (1995) The nuclear receptor superfamily: the second decade. Cell 83:835-839

3. Zhou Q, Nie R, Prins GS, Saunders PT, Katzenellenbogen BS, Hess RA (2002) Localization of androgen and estrogen receptors in adult male mouse reproductive tract. J Androl 23:870-881

4. Lucas TF, Siu ER, Esteves CA, Monteiro HP, Oliveira CA, Porto CS, Lazari MF (2008) 17beta-estradiol induces the translocation of the estrogen receptors ESR1 and ESR2 to the cell membrane, MAPK3/1 phosphorylation and proliferation of cultured immature rat Sertoli cells. Biol Reprod 78:101-114

5. Eddy EM, Washburn TF, Bunch DO, Goulding EH, Gladen BC, Lubahn DB, Korach KS (1996) Targeted disruption of the estrogen receptor gene in male mice causes alteration of spermatogenesis and infertility. Endocrinology 137:4796-4805

6. Robertson KM, O'Donnell L, Jones ME, Meachem SJ, Boon WC, Fisher CR, Graves KH, McLachlan RI, Simpson ER (1999) Impairment of spermatogenesis in mice lacking a functional aromatase (cyp 19) gene. Proc Natl Acad Sci USA 96:7986-7991

7. Zhou W, Bolden-Tiller OU, Shao SH, Weng CC, Shetty G, AbuElhija M, Pakarinen P, Huhtaniemi I, Momin AA, Wang J, Stivers DN, Liu Z, Meistrich ML (2008) Estrogen-regulated genes in rat testes and their relationship to recovery of spermatogenesis after irradiation. Biol Reprod 85:823-833

8. Pathak S, D'Souza R, Ankolkar M, Gaonkar R, Balasinor NH (2010) Potential role of estrogen in regulation of the insulin-like growth factor2-H19 locus in the rat testis. Mol Cell Endocrinol 314:110-117

9. Nam SY, Baek IJ, Lee BJ, In CH, Jung EY, Yon JM, Ahn B, Kang JK, Yu WJ, Yun YW (2003) Effects of 17beta-estradiol and tamoxifen on the selenoprotein phospholipid hydroperoxide glutathione peroxidase (PHGPx) mRNA expression in male reproductive organs of rats. J Reprod Dev 49:389-396

10. Piomelli D (2003) The molecular logic of endocannabinoid signalling. Nat Rev Neurosci 4:873-884

11. Di Marzo V (2009) The endocannabinoid system: its general strategy of action, tools for its pharmacological manipulation and potential therapeutic exploitation. Pharmacol Res 60:77-84

12. Maccarrone M (2009) Endocannabinoids: friends and foes of reproduction. Prog Lipid Res 48:344-354

13. Pertwee RG, Howlett AC, Abood ME, Alexander SP, Di Marzo V, Elphick MR, Greasley PJ, Hansen HS, Kunos G, Mackie K, Mechoulam R, Ross RA (2010) International union of basic and clinical pharmacology. LXXIX. Cannabinoid receptors and their ligands: beyond $\mathrm{CB}_{1}$ and $\mathrm{CB}_{2}$. Pharmacol Rev 62:588-631

14. Maccarrone M, Cecconi S, Rossi G, Battista N, Pauselli R, Finazzi-Agrò A (2003) Anandamide activity and degradation are regulated by early postnatal aging and follicle-stimulating hormone in mouse Sertoli cells. Endocrinology 144:20-28

15. Rossi G, Gasperi V, Paro R, Barsacchi D, Cecconi S, Maccarrone M (2007) Follicle-stimulating hormone activates fatty acid amide hydrolase by protein kinase A and aromatase-dependent pathways in mouse primary Sertoli cells. Endocrinology 148:1431-1439 
16. Grimaldi P, Orlando P, Di Siena S, Lolicato F, Petrosino S, Bisogno T, Geremia R, De Petrocellis L, Di Marzo V (2009) The endocannabinoid system and pivotal role of the CB2 receptor in mouse spermatogenesis. Proc Natl Acad Sci USA 106:1113111136

17. Rossato M, Ion Popa F, Ferigo M, Clari G, Foresta C (2005) Human sperm express cannabinoid receptor $\mathrm{Cb} 1$, the activation of which inhibits motility, acrosome reaction, and mitochondrial function. J Clin Endocrinol Metab 90:984-991

18. Maccarrone M, Barboni B, Paradisi A, Bernabò N, Gasperi V, Pistilli MG, Fezza F, Lucidi P, Mattioli M (2005) Characterization of the endocannabinoid system in boar spermatozoa and implications for sperm capacitation and acrosome reaction. J Cell Sci 118:4393-4404

19. Cravatt BF, Demarest K, Patricelli MP, Bracey MH, Giang DK, Martin BR, Lichtman AH (2001) Supersensitivity to anandamide and enhanced endogenous cannabinoid signaling in mice lacking fatty acid amide hydrolase. Proc Natl Acad Sci USA 98:93719376

20. Grimaldi P, Piscitelli D, Albanesi C, Blasi F, Geremia R, Rossi P (1993) Identification of $3^{\prime}, 5^{\prime}$-cyclic adenosine monophosphateinducible nuclear factors binding to the human urokinase promoter in mouse Sertoli cells. Mol Endocrinol 7:1217-1225

21. Perillo B, Ombra MN, Bertoni A, Cuozzo C, Sacchetti S, Sasso A, Chiariotti L, Malorni A, Abbondanza C, Avvedimento EV (2008) DNA oxidation as triggered by $\mathrm{H} 3 \mathrm{~K} 9 \mathrm{me} 2$ demethylation drives estrogen-induced gene expression. Science 319:202-206

22. Herman JG, Graff JR, Myöhänen S, Nelkin BD, Baylin SB (1996) Methylation-specific PCR: a novel PCR assay for methylation status of CpG islands. Proc Natl Acad Sci USA 93:98219826

23. Sewack GF, Ellis TW, Hansen U (2001) Binding of TATA binding protein to a naturally positioned nucleosome is facilitated by histone acetylation. Mol Cell Biol 21:1404-1415

24. Bauer UM, Daujat S, Nielsen SJ, Nightingale K, Kouzarides T (2002) Methylation at arginine 17 of histone H3 is linked to gene activation. EMBO Rep 3:39-44

25. Maor S, Mayer D, Yarden RI, Lee AV, Sarfstein R, Werner H, Papa MZ (2006) Estrogen receptor regulates insulin-like growth factor-I receptor gene expression in breast tumor cells: involvement of transcription factor Sp1. J Endocrinol 191:605-612

26. Varea O, Garrido J, Dopazo A, Mendez P, Garcia-Segura LM et al (2009) Estradiol activates $\beta$-catenin dependent transcription in neurons. PLoS One 4:e5153

27. Yore MA, Im D, Webb LK, Zhao Y, Chadwick JG Jr, MolendaFigueira HA, Haidacher SJ, Denner L, Tetel MJ (2010) Steroid receptor coactivator-2 expression in brain and physical associations with steroid receptors. Neuroscience 169:1017-1028

28. Maccarrone M, Bari M, Battista N, Finazzi-Agrò A (2002) Estrogen stimulates arachidonoylethanolamide release from human endothelial cells and platelet activation. Blood 100:40404048

29. Matthiesson KL, Stanton PG, O'Donnell L, Meachem SJ, Amory JK, Berger R, Bremner WJ, McLachlan RI (2005) Effects of testosterone and levonorgestrel combined with a 5alpha-reductase inhibitor or gonadotropin-releasing hormone antagonist on spermatogenesis and intratesticular steroid levels in normal men. J Clin Endocrinol Metab 90:5647-5655

30. Garcia-Bassets I, Kwon YS, Telese F, Prefontaine GG, Hutt KR, Cheng CS, Ju BG, Ohgi KA, Wang J, Escoubet-Lozach L, Rose DW, Glass CK, Fu XD, Rosenfeld MG (2007) Histone methylation-dependent mechanisms impose ligand dependency for gene activation by nuclear receptors. Cell 128:505-518

31. Metzger E, Wissmann M, Yin N, Müller JM, Schneider R, Peters AH, Günther T, Buettner R, Schüle R (2005) LSD1 demethylates repressive histone marks to promote androgen-receptor-dependent transcription. Nature 437:436-439

32. Lubahn DB, Moyer JS, Golding TS, Couse JF, Korach KS, Smithies O (1993) Alteration of reproductive function but not prenatal sexual development after insertional disruption of the mouse estrogen receptor gene. Proc Natl Acad Sci USA 90: 11162-11166

33. Hess RA, Bunick D, Lee KH, Bahr J, Taylor JA, Korach KS, Lubahn DB (1997) A role for oestrogens in the male reproductive system. Nature 390:509-512

34. Couse JF, Lindzey J, Grandien K, Gustafsson JA, Korach KS (1997) Tissue distribution and quantitative analysis of estrogen receptor-alpha (ERalpha) and estrogen receptor-beta (ERbeta) messenger ribonucleic acid in the wild-type and ERalphaknockout mouse. Endocrinology 138:4613-4621

35. Lemmen JG, Arends RJ, van Boxtel AL, van der Saag PT, van der Burg B (2004) Tissue- and time-dependent estrogen receptor activation in estrogen reporter mice. $\mathrm{J}$ Mol Endocrinol 32: 689-701

36. Barkhem T, Carlsson B, Nilsson Y, Enmark E, Gustafsson J, Nilsson S (1998) Differential response of estrogen receptor alpha and estrogen receptor beta to partial estrogen agonists/antagonists. Mol Pharmacol 54:105-112

37. Gruber CJ, Gruber DM, Gruber IM, Wieser F, Huber JC (2004) Anatomy of the estrogen response element. Trends Endocrinol Metab 15:73-78

38. Kato S, Yokoyama A, Fujiki R (2011) Nuclear receptor coregulators merge transcriptional coregulation with epigenetic regulation. Trends Biochem Sci 36:272-281

39. Fleury L, Gerus M, Lavigne AC, Richard-Foy H, Bystricky K (2008) Eliminating epigenetic barriers induces transient hormone-regulated gene expression in estrogen receptor negative breast cancer cells. Oncogene 27:4075-4085

40. Lande-Diner L, Zhang J, Ben-Porath I, Amariglio N, Keshet I, Hecht M, Azuara V, Fisher AG, Rechavi G, Cedar H (2007) Role of DNA methylation in stable gene repression. J Biol Chem 282: 12194-12200

41. Wissmann M, Yin N, Müller JM, Greschik H, Fodor BD, Jenuwein T, Vogler C, Schneider R, Günther T, Buettner R, Metzger E, Schüle R (2007) Cooperative demethylation by JMJD2C and LSD1 promotes androgen receptor-dependent gene expression. Nat Cell Biol 3:347-353

42. Shi L, Sun L, Li Q, Liang J, Yu W, Yi X, Yang X, Li Y, Han X, Zhang Y, Xuan C, Yao Z, Shang Y (2011) Histone demethylase JMJD2B coordinates $\mathrm{H} 3 \mathrm{~K} 4 / \mathrm{H} 3 \mathrm{~K} 9$ methylation and promotes hormonally responsive breast carcinogenesis. Proc Natl Acad Sci USA 108:7541-7546

43. Sun X, Wang H, Okabe M, Mackie K, Kingsley PJ, Marnett LJ, Cravatt BF, Dey SK (2009) Genetic loss of Faah compromises male fertility in mice. Biol Reprod 80:235-242

44. Orth JM, Gunsalus GL, Lamperti AA (1988) Evidence from Sertoli cell-depleted rats indicates that spermatid number in adults depends on numbers of Sertoli cells produced during perinatal development. Endocrinology 122:787-794

45. Waleh NS, Cravatt BF, Apte-Deshpande A, Terao A, Kilduff TS (2002) Transcriptional regulation of the mouse fatty acid amide hydrolase gene. Gene 291:203-210 